Abstracta Iranicacta Iranica

Revue bibliographique pour le domaine irano-aryen

Volume 32-33 | 2013

Comptes rendus des publications de 2009-2010

\title{
Margaret C. Miller. Luxury Toreutic in the Western Satrapies: Court-Inspired Gift-Exchange Diffusion
}

\section{Astrid Nunn}

\section{(2) OpenEdition}

1 Journals

\section{Édition électronique}

URL : http://journals.openedition.org/abstractairanica/40380

DOI : 10.4000/abstractairanica.40380

ISSN : 1961-960X

Éditeur :

CNRS (UMR 7528 Mondes iraniens et indiens), Éditions de l'IFRI

\section{Édition imprimée}

Date de publication : 1 décembre 2013

ISSN : 0240-8910

\section{Référence électronique}

Astrid Nunn, « Margaret C. Miller. Luxury Toreutic in the Western Satrapies: Court-Inspired Gift-Exchange Diffusion », Abstracta Iranica [En ligne], Volume 32-33 | 2013, document 102, mis en ligne le 01 juillet 2016, consulté le 05 octobre 2020. URL : http://journals.openedition.org/abstractairanica/40380 ; DOI : https://doi.org/10.4000/abstractairanica.40380

Ce document a été généré automatiquement le 5 octobre 2020.

Tous droits réservés 


\title{
Margaret C. Miller. Luxury Toreutic in the Western Satrapies: Court-Inspired Gift-Exchange Diffusion
}

\author{
Astrid Nunn
}

\section{RÉFÉRENCE}

Margaret C. Miller. «Luxury Toreutic in the Western Satrapies: Court-Inspired GiftExchange Diffusion », in : Bruno Jacobs, Robert Rollinger, éds., « Der Achämenidenhof / The Achaemenid Court ». Akten des 2. Internationalen Quolloquiums zum Thema « Vorderasien im Spannungsfeld klassischer und altorientalischer Überlieferungen ", Landgut Castelen bei Basel, 23.-25. Mai 2007. Wiesbaden, 2010, p. 853-897. (Classica et Orientalia(CLeO), 2)

1 L'A. essaie de reconstituer la culture matérielle dans les satrapies, comme le tente D. Kaptan (cf. c.r. $n^{\circ} 86$ ). Dans quelle mesure la province a-t-elle imité le centre, ou inversement, est-elle restée indépendante ? En effet, l'image des Achéménides qui n'ont pas imposé leur culture aux pays conquis fait partie de notre perception actuelle de cette dynastie. En fait, l'analyse de la toreutique et des nouvelles découvertes dans ce domaine montrent plutôt que les satrapies étaient une petite réplique des grands centres palatiaux, du moins en Anatolie. La forme des vases en métal précieux montre comment les éléments achéménides ont été incorporés dans le style local. Ils étaient fabriqués dans les ateliers satrapiques locaux et donnés en cadeau à l'élite locale qui appréciait cette nouvelle forme de prestige. 


\section{AUTEURS}

\section{ASTRID NUNN}

Université de Munich 